\title{
Contributions to the Geology of the Meguma Terrane, Nova Scotia
}

\author{
Edlted by \\ J. Duncan Kepple \\ Department of Mines and Energy \\ P.0. Box 1087, Hallfax, Nova Scotla, Canada B3J $2 \times 1$
}

Type setting and layout for this issue were funded by the Federal Government, Department of Energy, Mines and Resources, and printing costs were borne by the Nova Scotia Department of Mines and Energy under the Canada-Nova Scotia Mineral Development Agreement 1984-9.

A Special Issue

of

Maritime Sediments and At Iantic Geology

Vol. 22 , No. 1 


\section{Maritime Sediments and Atlantic Geology}

\section{Foreword \\ J. Duncan Keppie \\ (Editor)}

During the period between 1981 and 1984, the eastern end of the Meguma Terrane was investigated under the Canada - Nova Scotia Co-operative Mineral Program. This program involved geologists from both Federal and Provincial Governments and a number of universities. It provided the first comprehensive remapping since the excellent mapping undertaken by E. H. Faribault around the turn of the century. The remapping was supported by airborne gradiometry and radiometry and formed the basis for multidisciplinary studies into various aspects of the geology, especially gold metallogeny. These studies, together with those in other parts of the Meguma Terrane, formed the basis for a Symposium at the Northeastern Section of the Geological Society of America in March, 1984. The papers in this volume represent a collection of several presented at the Symposium. Other papers on the topic have already been published in the Geological Survey of Canada Papers 83-1 and 84-1, the Nova Scotia Department of Mines and Energy Papers 83-1 and 84-1, and in the Canadian Institute of Mining and Metallurgy Division, Excursion Guidebook entitled "Gold Deposits in the Meguma Terrane of Nova Scotia", 1983. A symposium on "Turbidite-Hosted Gold Deposits" was held at the Geological Association of Canada Annual Meeting in Fredericton, 1985 followed by publication of a collection of papers in a Geological Association of Canada Special Paper. Some of these papers deal with gold deposits in the Meguma Terrane. A field trip to several gold deposits in the Meguma Terrane, augmented by a field guidebook, followed the Symposium. Undoubtedly, other results of these studies will continue to be published.

Each paper in this volume was reviewed by two independent reviewers whose comments were used to determine whether the paper was acceptable for publication. The editor takes this opportunity for thanking the reviewers for their assistance; their contribution lead to improvements in the papers. The reviewers were: J. Chandra, A. K. Chatterjee, D. B. Clarke, G. Cumming, K. Currie, J. Dostal, W. Fyson, S. J. Haynes, J. Henderson, R. V. Kirkham, H. Massone, B. H. O'Brien, K. H. Poulsen, P-Y Robin, D. F. Sangster, P. K. Smith, R. Thorpe, T. Wright and $M$. Zentilli. I would also like to thank P. Ledwidge for translating all but one of the abstracts. 